\title{
EVALUATING FINANCIAL PERFORMANCE IN LOCAL GOVERNMENT: A STUDY IN SOUTH SULAWESI PROVINCE (INDONESIA)
}

\author{
${ }^{1}$ Ramadhan Pirade, ${ }^{2} \mathrm{H}$. Abdul Rahman Mus, ${ }^{3} \mathrm{Hj}$. Masdar Mas'ud, ${ }^{4} \mathrm{Hj}$. Andi Nirwana Nur \\ ${ }^{1}$ Doctoral Student, University of Muslim Indonesia \\ ${ }^{2,3,4}$ Faculty of Economics, University of Muslim Indonesia
}

\begin{abstract}
This study investigates the financial performance measurement (fiscal decentralization, allocation of capital expenditure, economic growth effect on the regional own revenue) in South Sulawesi Province (Indonesia) local government. The database used is sourced from the Central Statistics Agency and the financial statements 24 County and City on 2012-2016, in order to obtain a total sample of 120 units of the sample. The results of the panel regression analysis using Eviews program 9 shows that increasing fiscal decentralization, capital expenditure and hence economic growth increasingly important role in increasing on the regional own revenue. Recommendations of these studies to the parties concerned to be pursued acceleration of economic growth quality and useful for the improvement of the regional own revenue (PAD) and creating equitable economic growth, especially in economic sectors that are closely related to the acceptance of the PAD. This study is very important that further research is necessary to perform additional variables with a longer observation time. Later research can also be done in other provinces in the entire territory of the Republic of Indonesia even more wide-ranging.
\end{abstract}

Keywords: Decentralization, capital expenditure, growth, regional own revenue

\section{INTRODUCTION}

Granting authority to every region of course is the essential basis for the implementation of regional autonomy in which areas have enough range of motion in its potential uses, both coming from the region itself and from the central government administration saw fit and welfare. In order to carry out activities in the area, auto-area must have the funds or the cost. Without sufficient funds or fees, the implementation of activities in the area cannot be implemented. The increase in local revenues in the province of South Sulawesi shows that with the implementation of local autonomy is expected that all regions can carry out government affairs and development 
International Journal of Arts and Humanities

ISSN: 2581-3102

Volume:02, Issue:03 "March 2018"

by relying on the regional own revenue (PAD) has. Various sources of revenue are expected to boost per capita income of the area through various types of expenditure or increase government spending to stimulate social and economic activities of society so as to reduce poverty in the area. An area that is capable of performing well autonomy can be seen in the financial capability and dependence on assistance center should be as minimum as possible, therefore, the regional own revenue should be the biggest financial source supported by the policies of central and local financial balance (Halim, 2008).

The phenomenon is seen that the regions with abundant natural resources, and there are also areas that do not have great natural wealth, but because of the economic structure that is already well, then the tax potential can be optimized so that the area becomes rich. But there are still many areas that natural and economic structure is still very behind, so we need a mechanism to regulate financial balance between the centers of the area in order to finance the tasks assigned to local governments. Mechanisms are the central government transfers funds in the form of tax revenue for non-tax results (natural resources), General Allocation Fund (DAU) and Special Allocation Fund (DAK). This transfer of funds used to finance the operations of the regional government in Regional District and the City of South Sulawesi Province.

South Sulawesi province in 2016 is experiencing an economic growth of 7.41 percent (year on year). Growth almost occurred in all economic categories with the highest growth generated by the Financial Services category. Each year since the year 2010 - 2016, the economic growth of South Sulawesi was above the national economic growth. Based on the realization of budget absorption maximum in 2012-2016 is still used for the realization of capital expenditure is much smaller than the actual expenditure. The capital expenditure is incurred by the government budget to finance programs or activities of each work unit area. The costs of local government covers all expenses associated with either the regional development spending to run the government as well as to finance all the economic activities in an area. Capital expenditure is expected to drive regional economic growth that can spur poverty reduction so as to improve the welfare of society.

Research on the effect between fiscal decentralization and the regional own revenue on capital expenditure and economic growth has been done by several researchers. Previous research proved that the effect of fiscal decentralization on economic growth (Yamoah, 2007; Aisha, 2008; Elida, 2013). Fiscal decentralization and PAD has a significant effect on the allocation of capital expenditure. Economic growth is not directly affected by fiscal decentralization through allocation of capital expenditure (Sularso and Restianto, 2011). Regional own revenue and profit sharing fund (DBH) significant impact on poverty reduction (Santosa, 2013). General allocation fund, direct expenditure and economic growth effect on poverty (Paseki et al. 2014). The results 
are gained debate with other studies that the fiscal decentralization negatively affects on economic growth (Bodman et al., 2009). Regional Shopping allocation had no effect on poverty (Pratomo, 2015).

\section{THEORETICAL FRAMEWORK}

\section{Local government finance}

Grand theory used in this research is the theory of the welfare state; the government has a responsibility to ensure the greatest happiness (welfare) of the greatest number of Reviews their citizens. Happiness or well-being or the so-called utility can be achieved through legal reform, the role of the constitution and social studies for the development of social policy (Smith and Grønbjerg, 2006). The financial performance is the level of attainment of a target for local government finances as measured by financial indicators which can be judged from the accountability of the Regional Budget (APBD) (Halim, 2007).

\section{Regional own revenue (PAD)}

Regional income is cash replenishment of the central government are derived from various sources, among others, include tax receipts, excise, oil revenues, revenues from investments, receiving foreign aid and domestic loans and grants (Gade, 2000: 100). The views of other scholars explain that the local revenue is all cash receipts into the right area and is recognized as an addition to net worth in one fiscal year and does not have to be repaid by the government (Yuwono, 2005).

Government revenue can be distinguished between tax and non-tax. Non-tax revenues, such as the government's revenue comes from government loans, good loans from domestic and government borrowing from abroad. PAD is the revenue that the region from sources within its own territory which is levied according to local regulations. In the context of regional development financing, genuine potential resource area is the entire area that has the potential to be developed so as to give the economic value that can be used as a source of financing regional development. While entirely by local management is the delivery throughout the management of these resources to the areas concerned (Suhanda, 2007: 82).

\section{Fiscal Decentralization}

Fiscal decentralization is the transfer of power of government by the central government to autonomous regions within the framework of the Unitary Republic of Indonesia. While fiscal decentralization can be interpreted as a delegation of authority in the field of finance budget 
revenue or previously centralized, both the administration and utilization organized or carried out by the central government (Khusaini, 2006).

Studies conducted Bodman et al. (2009) provide evidence that fiscal decentralization does not have a significant impact on the distribution of income but a negative impact on economic growth. The different results obtained by other researchers, that fiscal decentralization has a positive effect on economic growth (Aisha, 2008; Elida, 2013).

Based on these descriptions, we make the hypothesis in this study as follows.

$\mathrm{H}_{1}$ : Fiscal decentralization effect on regional own revenue (PAD)

\section{Capital Expenditure}

The capital expenditure is the government spending that benefits area exceeding 1 year budget and will add a wealth of assets or regions and will further augment routine expenditure such as maintenance costs on public administration expenditure group (Halim, 2008). The views of other scholars explain that the capital expenditure is the government spending that resulted in certain assets (Nordiawan and Hertianti, 2006). The capital expenditure is the expenditure made in the context of capital formation in nature add to the fixed asset / inventory that benefit more than one accounting period, including the expenses for maintenance of the nature preserve or add to the useful life, increase the capacity and quality of the assets (Dougan and Kenyon, 1988).

Indonesian Government Regulation No. 71 Year 2010, capital expenditure is the expenditure of Local Government whose benefits exceed one year budget and will add a wealth of assets or regions and will further augment routine expenditure such as maintenance costs on public administration expenditure groups. The capital expenditures are used to acquire fixed assets of local government such as equipment, infrastructure and other fixed assets. How to get the capital expenditure are buying through auction or tender process. Increased local government capital expenditures is expected to improve the quality of public services and in turn can increase the level of participation (contribution) to the development of public, as reflected in an increase in revenue (Mardiasmo, 2002).

Industrial infrastructure development has a real impact on local tax increases (Wong, 2004). Development spending gives a positive and significant impact on revenue. In other words, the construction of various public sector facilities will lead to an increase in local revenue. In the implementation of decentralization, development is a top priority of local governments to support an increase in revenue (Adi, 2006). Research conducted by Abdullah and Halim (2003) shows the influence of a strong shopping area to increased revenue. Capital expenditure is significant effect on economic growth (Sularso and Restianto, 2011). 
Based on these descriptions, we make the hypothesis in this study as follows

$\mathrm{H}_{2}$ : The allocation of capital expenditure has positive effect on regional own revenue (PAD)

\section{Economic Growth}

Economic growth is most simply be defined as output increment or increase aggregate national income within a certain period, say one year (Prasad, 2009). The economy of a country is said to be experiencing real growth if fringe benefits of the use of factors of production in a given year is greater than in previous years. Thus, the notion of economic growth can be interpreted as an increase in the production capacity of physical goods and services within a certain time. An economy is said to grow if there is an increase in output per capita in the long term, economic growth as a quantitative measure that describes the development of an economy in a given year when compared with the previous year (Sukirno, 2006).

Economic development can also be defined as a process that led to the increase in income per capita of a country over the long term is accompanied by improvement of the institutional system (Arsyad, 2004). Changes in the economy will provide meaningful impact on changes in revenue (PAD). An area that has a good economy will have high revenue. With so it can be said that the better the economic conditions of an area will support to increase revenue (Saragih and Khadafi, 2003). Local revenues have a part to finance the implementation of regional autonomy in order to achieve the goal of regional autonomy that want to improve public services and promote the local economy (Mardiasmo, 2002). Economic growth is a positive and significant impact on revenue (PAD) (Desmawati et al. 2015).

Based on these descriptions, we make the hypothesis in this study as follows

$\mathrm{H}_{3}$ : Economic growth affects on regional own revenue (PAD)

\section{METHODS}

This study uses a quantitative approach aimed at identifying the variables, and sees the relationship between variables, with each other through the statistics to reject or accept the hypothesis. The sample used in this study consisted of 24 districts / municipalities in South Sulawesi province. The data used is limited to budget data that will be used to analyze the financial performance of the province of South Sulawesi total revenues, capital expenditures, and local revenues as well as statistical data sourced from Statistics form of data the poverty rate, the GDP in 2012-2016, and financial data of South Sulawesi province. This study uses panel data which is a combination of time series and cross-sectional analysis using multiple linear regression models with Eviews Program 9 as a data analysis tool. 
International Journal of Arts and Humanities

ISSN: 2581-3102

Volume:02, Issue:03 "March 2018"

\section{RESULTS}

The results of descriptive statistical analysis of research variables can be seen in the following table.

Table 1: Descriptive statistics

\begin{tabular}{l|c|c|c|c}
\hline \multicolumn{1}{c|}{ description } & $\log \mathrm{Y}$ & $\log \mathrm{X}_{1}$ & $\log \mathrm{X}_{2}$ & $\log \mathrm{X}_{3}$ \\
\hline Mean & 18.01644 & 1.976726 & 19.07265 & 15.71659 \\
\hline Median & 17.98465 & 1.925687 & 19.08664 & 15.51377 \\
\hline Maximum & 20.98961 & 3.574261 & 20.46930 & 20.12238 \\
\hline Minimum & 16.51646 & 0.861223 & 16.60682 & 14.56825 \\
\hline Std. Dev. & 0.809992 & 0.524720 & 0.562981 & 0.841316 \\
\hline Skewness & 0.822704 & 0.533572 & 0.493335 & 2.215843 \\
\hline Kurtosis & 4.532598 & 3.238349 & 4.768448 & 10.07284 \\
\hline Jarque-Bera & 25.28113 & 5.978031 & 20.50463 & 348.3247 \\
\hline Sum & 2161.972 & 237.2071 & 2288.719 & 1885.991 \\
\hline Sum Sq. Dev. & 78.07440 & 32.76446 & 37.71672 & 84.22968 \\
\hline Observations & 120 & 120 & 120 & 120 \\
\hline Cross sections & 24 & 24 & 24 & 24 \\
\hline
\end{tabular}

After the descriptive statistical analysis, the stages of research carried out by using classic assumption test:

\section{Heterocedastisity test}

Heterocedastisity test gives the sense that there is a difference in a model of the residual variance on observation. Inside there is a good model of any heterocedastisity. The test of heterocedastisity in this study can be seen in the following table.

Table 2: Heterocedastisity test

\begin{tabular}{ccccc}
\hline Variable & Coefficient & Std. Error & t-Statistic & Prob. \\
\hline $\mathrm{C}$ & 6.619319 & 1.783416 & 3.7115956 & 0.0602 \\
$\log \mathrm{X} 1$ & 1.11051 & 0.141939 & 7.8238539 & 0.0573 \\
$\log \mathrm{X} 2$ & 0.346919 & 0.097916 & 3.5430267 & 0.0819 \\
$\log \mathrm{X} 3$ & 0.164494 & 0.055235 & 2.9780755 & 0.1094 \\
\hline
\end{tabular}

Multicollinearity test 
Regression is said to be good if a regression does not have multicollinearity in it so there is no disruption expected to occur in the regression. Multicollinearity test is used to determine whether or not the relationship between the independent variables in the study. The test of multicollinearity in this study can be seen in the following table.

Table 3: Multicollinearity test

\begin{tabular}{cccc}
\hline description & $\log \mathrm{X} 1$ & $\log \mathrm{X} 2$ & $\log \mathrm{X} 3$ \\
\hline $\log \mathrm{X} 1$ & 1.000000 & 0.691458 & 0.605514 \\
$\log \mathrm{X} 2$ & 0.691458 & 1.000000 & 0.647249 \\
$\log \mathrm{X} 3$ & 0.605514 & 0.647249 & 1.000000 \\
\hline
\end{tabular}

\section{Normality Test}

Normality test referred to in classical assumptions OLS approach is residuals formed normally distributed regression model, not the independent or dependent variable. Tests on the residuals are normally distributed or cannot use the Jarque-Bera test. How to determine the normal distribution of data is to compare the Jarque-Bera test.

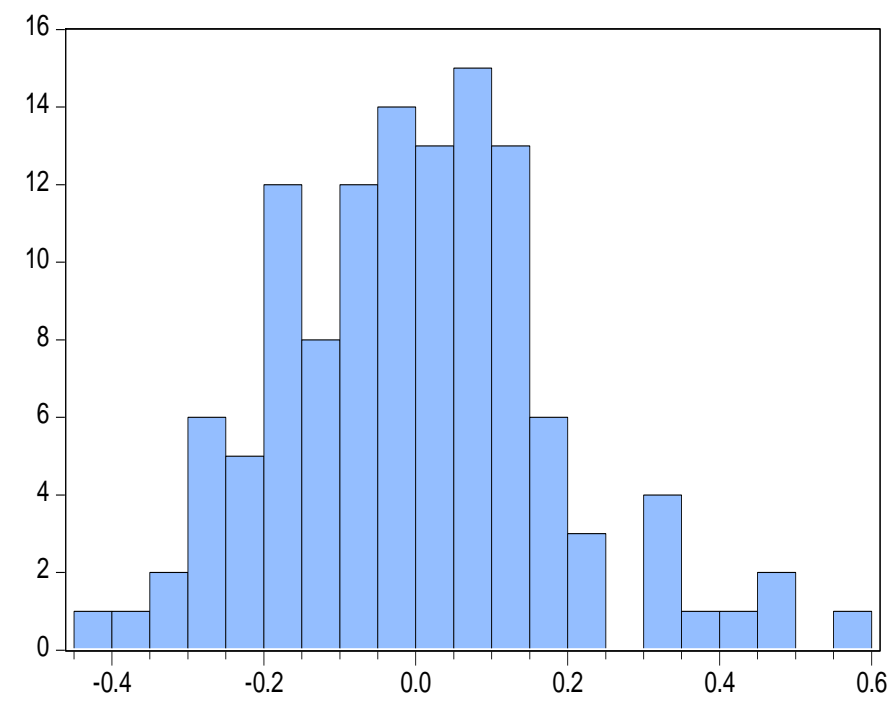

\begin{tabular}{|ll}
\hline Series: Standardized Residuals \\
Sample 2012 2016 \\
Observations 120 \\
Mean & $4.42 \mathrm{e}-17$ \\
Median & -0.003373 \\
Maximum & 0.563693 \\
Minimum & -0.426500 \\
Std. Dev. & 0.180978 \\
Skewness & 0.425321 \\
Kurtosis & 3.438339 \\
& \\
Jarque-Bera & 4.578670 \\
Probability & 0.101334 \\
\hline
\end{tabular}

Figure 1: Normality of Data

\section{Analysis Model Selection}

Selection panel testing methods performed on the entire sample data (i.e.: 21 counties and 3 cities) to do the Chow and Hausman test, for the second test will be described below. 


\section{Chow test}

Chow test is a test to determine the best model among fixed effect to the common / pool effect. If the result is expressed accept the null hypothesis that the best model to use is a common model. But if the results are expressed reject the null hypothesis that the best model used is the fixed effect, and testing will continue to Hausman test. The chow test in this study can be seen in the following table.

\section{Table 4: Chow test}

\begin{tabular}{lccc}
\hline \multicolumn{1}{c}{ Effects Test } & Statistic & d.f & Prob. \\
\hline Cross-section F & 2.891662 & $(23,93)$ & 0.0002 \\
Cross-section Chi-square & 64.739519 & 23 & 0.0000 \\
\hline
\end{tabular}

The best model used is the model by using fixed effect. Based on the results of the Chow test reject the null hypothesis, then testing the data continues to Hausman test.

\section{Hausman test}

Hausman Test is a test to determine the method of use random with fixed effect. If the results of the Hausman test the null hypothesis states receive the best model to use is a model random effect. However, if the result is declared then reject the null hypothesis that the model used is a model fixed effect.

\section{Table 5: Hausman test}

\begin{tabular}{cccc}
\hline Test Summary & Chi-Sq. statistik & Chi- S.q d.f & Prob. \\
\hline Cross-section random & 9.120842 & 3 & 0.0277
\end{tabular}

\section{Panel Data Model Analysis}

\section{Panel Data Regression}

The electoral models use the best analysis test. The regression analysis based on data obtained three research panel regression models, namely: common effect model, fixed effect model and random effect model presented in Table 6 below. 
International Journal of Arts and Humanities

ISSN: 2581-3102

Volume:02, Issue:03 "March 2018"

Table 6: Estimates of common effect, fixed effects and random effect

Dependent variabel: PAD

Kontanta (C)
Standar error
t-Statistik
Probability
fiscal decentralization
Standar error
t-Statistik
Probability
allocation of capital expenditure
Standar error
t-Statistik
Probability
economic growth
Standar error
t-Statistik
Probability
$\mathrm{R}^{2}$
F-Statistik
Prob (F-Stat)
Durbin-Watson Stat

Common

6.619319

1.783416

3.711596

0.0602

1.110510

0.141939

7.823854

0.0573

0.346919

0.097916

3.543027

0.0819

0.164494

0.055235

2.978075

0.1094

0.944888

662.9322

0.000000

0.987433
Model

Fixed Effect

8.510077

1.976150

4.306392

0.0310

1.180565

0.161269

7.320471

0.0036

0.322500

0.079398

4.061815

0.0264

0.065013

0.020205

3.217669

0.0393

0.967867

107.7402

0.000000

1.554508
Random

7.169972

1.681060

4.265149

0.0314

1.149608

0.144655

7.947240

0.0010

0.339244

0.084562

4.011778

0.0358

0.133853

0.056658

2.362473

0.0416

0.928368

501.1285

0.000000

1.244627

Based on the test specifications of the model that has been done in the above table of both analyzes were performed using likelihood and Hausman test both suggested to using a fixed effect model, and from a comparison of the best electoral test the regression model used is the fixed effect model. Approach Fixed Effect produces all significant variables. $\mathrm{R}^{2}$ value is generated also look better by using approach Fixed Effect Model to the value of $\mathrm{R}^{2}$ 0,967867dengan DW 1.55, which means there is no autocorrelation. However, for the selection of a good model selection model based test with regard to the outcome of statistical calculations to determine the approach used regression models.

\section{Panel Data Model Estimation}

Based on model specification test has been performed as well as from a comparison of the best value then the panel data regression model used is fixed Effect Model (FEM). The following 
International Journal of Arts and Humanities

ISSN: 2581-3102

Volume:02, Issue:03 "March 2018"

table shows the results with the number of observation data estimates as many as 24 districts and cities during the period 2012-2016.

Table 7: Fixed effect model estimation

\begin{tabular}{lr}
\hline \multicolumn{1}{c}{ Dependent variabel : PAD } & Fixed Effect \\
\hline Constant & 8.510077 \\
Standar error & 1.976150 \\
t-Statistik & 4.306392 \\
Probability & 0.0310 \\
fiscal decentralization & 1.180565 \\
Standar error & 0.161269 \\
t-Statistik & 7.320471 \\
Probability & 0.0036 \\
allocation of capital expenditure & 0.322500 \\
Standar error & 0.079398 \\
t-Statistik & 4.061815 \\
Probability & 0.0264 \\
economic growth & 0.065013 \\
Standar error & 0.020205 \\
t-Statistik & 3.217669 \\
Probability & 0.0393 \\
$\mathrm{R}^{2}$ & 0.967867 \\
F-Statistik & 107.7402 \\
Prob (F-Stat) & 0.000000 \\
Durbin-Watson Stat & 1.554508 \\
\hline
\end{tabular}

Based on estimates of the above, it can be made model of panel data analysis of the factors that affect the regional own revenue at districts and cities in South Sulawesi which concluded with a regression equation of panel data as follows:

$\log (Y)=\beta 0-\beta 1 * \log X_{1}+\beta 2 * \log X_{2}+\beta 3 * \log X_{3}+$ et

$\log (\mathrm{Y})=8.510077+1.180565 *$ LOGX1 $+0.322499 *$ LOGX2 $+0.065012 *$ LOGX3 + et

t-Statistic

t- Statistic is a partial hypothesis testing, used to download getahui whether the independent variables (fiscal decentralization, allocation of capital expenditure and economic growth) has an impact and relationship to the PAD. The results of the partial test ( $t$ test) can be seen in the following table. 
International Journal of Arts and Humanities

ISSN: 2581-3102

Volume:02, Issue:03 "March 2018"

Table 8: t-Statistic

\begin{tabular}{lcc}
\hline \multicolumn{1}{c}{ Variable } & Regression coefficient & Prob. \\
\hline fiscal decentralization & 1.180565 & 0.0036 \\
capital expenditure & 0.322500 & 0.0264 \\
economic growth & 0.065013 & 0.0393 \\
\hline
\end{tabular}

From the results if the datausing the Fixed Effect Model obtained R-squared value of 0.967867 (Table 7), means for $96.7867 \%$ of the independent variables (fiscal decentralization, capital expenditure and economic growth) affect the regional own revenue and the remaining $3.2133 \%$ are influenced by other independent variables out of the study.

\section{Effect of fiscal decentralization on regional own revenue (PAD)}

The role of fiscal decentralization policy in an increase in local revenues and district and city in South Sulawesi province can be seen from the results of the panel data model estimation. The results of the partial test (t-test) showed a significant effect of fiscal decentralization and positive impact on revenue in the region of South Sulawesi province. Fiscal decentralization coefficient values obtained by 1.180565 , meaning that if the fiscal decentralization increased by 1 unit, then the PAD increased by 1.180565 assuming a fixed revenue. This suggests that fiscal decentralization is capable of supporting an increase in revenue of Districts and Municipalities in the province of South Sulawesi. Fiscal decentralization policy which has implications for local governments to further intensify and broaden the taxation of services that contribute to a genuine acceptance of Courant levy.

Fiscal decentralization (in autonomy) is intended to create the region's autonomy. Decentralization of government which can either be done by holding a clear financing in the implementation, by providing equalization funds to local governments that sealed-sanakan on the basic principles of decentralization, deconcentration and assistance task. In addition to funding the balance, the central government also provides an opportunity for local governments to increase revenue through intensification and extension of tax and levies to finance the needs of the region. The findings of this study are consistent with results of previous studies that fiscal decentralization significant and positive impact on revenue (Purwantoro and Akbar, 2007; Bahl and Wallace, 2001). Yamoah rejected the findings of the study (2007) that fiscal decentralization negatively affect revenue.

Effect of capital expenditure on regional own revenue (PAD) 
Regional own revenue role of capital expenditure policies in increasing local revenues and City District in South Sulawesi province can be seen from the results of the panel data model estimation. The results of the partial test (t-test) showed that capital spending is significant and positive impact on revenue in the region of South Sulawesi province. Capital expenditure coefficient values obtained for 0.322499 means that while capital expenditure increased by one unit, then the PAD increased by 0.322449 assuming a fixed revenue. This suggests that capital spending is able to support an increase in revenue of districts and municipalities in the province of South Sulawesi. These findings indicate that the amount of local revenue until now have been determined by the capital expenditure.

This study supports research by Adi (2006) which states that construction spending provides a positive and significant impact on regional revenue. Industrial infrastructure development has a real impact on the increase in local taxes, local taxes are part of regional revenue, so it can be interpreted by the government capital expenditure will impact revenue increased PAD (Wong, 2004). The study's findings are consistent with the results by Solikin (2007) that there is a strong positive relationship between capital belnaja with revenue. Other researchers have proved that there is a positive and significant relationship between the shopping area with revenue. This means that the higher the local revenue on capital expenditures in government spending would be even higher (Daryanto and Yustikasari, 2007).

\section{Effect of Economic Growth on regional own revenue (PAD)}

The policy role of economic growth in local revenues increase of districts and municipalities in South Sulawesi province can be seen from the results of the panel data model estimation. The results of the partial test (t-test) showed significant growth and positive impact on revenue in the region of South Sulawesi province. Economic growth coefficient values obtained by 0.065012 mean that when the economy grew by 1 unit, then the PAD increased by 0.343433 assuming fixed revenue. This suggests economic growth contributed to the increase in revenue of districts and municipalities in South Sulawesi province.

Economic growth affects the increase in revenue (PAD) PAD which should ideally be the main source of local government costs to run the regional development. Areas that have a positive economic growth are likely to get the increase in revenue. This should make local government more concentrated on the empowerment of the local economy to create economic growth rather than simply issuing product related legislation or tax levies. Saragih and Gaddafi (2003) states that any change in economic conditions will provide meaningful impact on changes in revenue (PAD). 
International Journal of Arts and Humanities

ISSN: 2581-3102

Volume:02, Issue:03 "March 2018"

An area that has a good economy will have high revenue. With so it can be said that the better the economic conditions will support the local ne to increased revenues. Thus, it can be said that the region's economy in a positive effect on revenue. The study's findings are consistent with the results of research conducted by Desmawati et al. (2015) found a significant effect of economic growth on revenue. This means that economic growth is effective in increasing revenue or economic growth has spread in the economic sector which is a source of revenue for PAD.

\section{CONCLUSION}

Fiscal decentralization positive significant and impact on revenue that the fiscal decentralization increasingly of regional own revenue. Capital expenditure of significant and positive impact on revenue that increased the capital expenditure of regional own revenue will increase as well. Economic growth is significant and positive impact on regional own revenue that increasing the economic growth of regional own revenue will increase as well. Areas that have the effect of cross-section that is positive is Bulukumba, Jeneponto, Takalar, Gowa, Sinjai, Bone, Soppeng, Wajo, Maros, Pangkep, Pinrang, Tana Toraja and East Luwu, North Luwu and then Makassar and Palopo city. In contrast to areas that have a negative influence are Selayar District, Bantaeng, Barru, Sidrap, Enrekang, Luwu, North Toraja and Parepare.

\section{REFERENCES}

[1] Jones, L. R., \& Kettl, D. F. (2003). Assessing public management reform in an international context. International Public Management Review, 4(1), 1-19. http://journals.sfu.ca/ipmr/index.php/ipmr/article/view/206/206

[2] Abdullah, S., \& Halim, A. (2003). The influence of the general allocation fund (DAU) and revenue (PAD) to the local government expenditure: A case study of districts / Cities in Java and Bali. Proceedings of the National Accounting Symposium VI, 16-17.

[3] Adi, PH (2006). The relationship between regional economic growth, development expenditure and revenue. Accounting in the National Symposium IX Padang.

[4] Aisyah. (2008). The Effect of Fiscal Decentralization on Economic Growth. Graduate School of Development Studies. Institute of Social Studies. Netherlands

[5] Arsyad, Lincolin. (2004). Economic development. Yogyakarta: STIE YKPN

[6] Bahl, RW, \& Wallace, S. (2001). Fiscal Decentralization: The Provincial-Local Dimension. Fiscal Policy Training Program, 2001.

[7] Bodman, P., Heaton, KA, \& Hodge, A. (2009). Fiscal Decentralization and economic growth: A Bayesian models of the averaging approach. School of Economics, University of Queensland, Australia. 
International Journal of Arts and Humanities

ISSN: 2581-3102

Volume:02, Issue:03 "March 2018"

[8] Darwanto \& Yulia Yustikasari. (2007). "Effect of Economic Growth, Local Revenue and the General Allocation Fund to the Capital Expenditure Budget Allocation". National Symposium on Accounting 10 Napier.

[9] Desmawati, A., Zamzami, Z., \& Zulgani, Z. (2015). The influence of economic growth on revenue districts / cities in Jambi province. Financing journal Perspectives and Regional Development, 3 (1), 49-58.

[10] Dougan, WR, \& Kenyon, DA (1988). Pressure groups and public expenditures: The flypaper Reconsidered. Economic Inquiry, 26 (1), 159-170.

[11]Elida, SWR (2013). The Effect of Regional Fiscal Policy on Regional Economic Growth (Case Study: Provinces in Kalimantan, Indonesia). International Institute of Social Studies.

[12] Halim, Abdul. (2007). Regional Financial Accounting. Jakarta. Salemba Empat.

[13] Halim, Abdul. (2008) Regional Financial Accounting. Jakarta, Salemba Empat.

[14] Khusaini, M. (2006). Fiscal Decentralization Study. The effect on the Economic Efficiency of Public Sector, Regional Economic Growth and Public Welfare, Dissertation (S3), Department of Economics, majoring in Development Studies, the Graduate Program, University of Brawijaya, Malang.

[15] Mardiasmo, (2002). Economics and Financial Management Areas, Publisher Andi. Yogyakarta.

[16] Muhammad Gade. (2000). .Akuntansi Government. Jakarta: Issuing Faculty of Economics, University of Indonesia.

[17] Nordiawan, D., \& Hertianti, A. (2006). Public sector accounting. Jakarta: Four Salemba.

[18] Paseki, M., Naukoko, A., \& Wauran, P. (2014). Effect of General Allocation Funds and Direct Expenditure Against Economic Growth and Its Impact on Poverty in Manado City Year 2004-2012. Efficiency Scientific Periodical Journal, 14 (3).

[19] Prasetyo, PE (2009). Macroeconomic fundamentals. Yogyakarta: Beta Offset.

[20] Pratomo, AA, \& Hendarto, RM (2015). The influence PAD, General Allocation Fund, DBH And Regional Shopping DKI Jakarta Against Poverty Level (Doctoral dissertation, Faculty of Economics and Business).

[21]Purwantoro, A., \& Akbar, R. (2007). The influence of fiscal decentralization to local revenues and public expenditure districts / cities in Java (Doctoral dissertation, University of Gadjah Mada).

[22] Republic of Indonesia. (2010) of Government Regulation No. 71 of 2010 on Accounting Standards. Government.

[23] Sadono, Sukirno. (2006) Process Development Economics and Policy Issues. Jakarta: Faculty of Economics, University of Indonesia. 
[24] Santosa, B. (2013). Effect of Revenue daeah And Regional Balance Fund on Growth, Unemployment And Poverty 33 provinces in Indonesia. Journal of Finance \& Business Management Master Program Hope High School of Economics, 5 (2), 130-143.

[25] Saragih, JP, \& Khadafi, MS (2003). Fiscal Decentralization and Local Financial Autonomy. Publisher Ghalia Indonesia.

[26] Smith, SR, \& Grønbjerg, KA (2006). Scope and theory of government-nonprofit relations. The nonprofit sector: A research handbook, 2, 221-242.

[27] Solikin, I. (2007). Relationships source revenue and general allocation fund with capital expenditures in West Java.

[28] Suhanda. (2007). Financial Accounting Local Government. Padang. Andalas Five Sides

[29] Sularso, H., \& Restianto, YE (2012). The influence of the financial performance of capital expenditure and economic growth in the district / city in Central Java. Media Research Accounting, 1 (2).

[30]Wong, JD (2004). The fiscal impact of the economic growth and development on local government revenue capacity. Journal of Public Budgeting, Accounting and Financial Management, 16 (3), 413-423.

[31] Yamoah, AB (2007). The effects of fiscal decentralization on economic growth in US counties (Doctoral dissertation, The Ohio State University). 